\title{
The Effect of Visual and Auditory Input Enhancement on Vocabulary Acquisition of Iranian EFL University Students
}

\author{
Ali Ghafouri ${ }^{1} \&$ Mohsen Masoomi ${ }^{2}$ \\ ${ }^{1}$ Department of English Language, Kurdistan Science and Research Branch, Islamic Azad University, Sanandaj, \\ Iran \\ ${ }^{2}$ Department of English, Sanandaj Branch, Islamic Azad University, Sanandaj, Iran \\ Correspondence: Ali Ghafouri, Department of English Language, Kurdistan Science and Research Branch, \\ Islamic Azad University, Sanandaj, Iran. E-mail: ali20020ali@yahoo.com or masoomi.mohsen@outlook.com
}

Received: August 7, 2016 Accepted: August 30, 2016 Online Published: December 1, 2016

doi:10.5539/ijel.v6n7p81 URL: http://dx.doi.org/10.5539/ijel.v6n7p81

\begin{abstract}
This study was an attempt to investigate the effect of input enhancement instruction on vocabulary acquisition among Iranian university students. Moreover, the possible effect of two kinds of input enhancement (i.e., auditory and visual) was examined. To this end, 75 Iranian university students, majoring English language Teaching at Applied Science and Technology of Kurdistan University, Iran, were randomly selected. The method used in this study was quantitative research and the true experimental design. One experimental group received vocabulary instruction via visual input enhancement, and the other experimental group was taught vocabulary via auditory input enhancement. After administering the posttest, the dada was analyzed by one-way ANOVA. The findings revealed that both auditory and visual input enhanced instruction had a significant effect on the vocabulary development of Iranian EFL students. In addition, comparing the efficacy of two types of instruction, the results indicated that the effect of either visual or auditory input enhancement for both experimental EFL university students were fairly the same in Iranian EFL educational setting.
\end{abstract}

Keywords: input enhancement, visual input enhancement, auditory input enhancement, vocabulary acquisition, Iranian EFL students

\section{Introduction}

\subsection{Introduce the Problem}

Input enhancement is grounded in models of SLA, such as Gass (1997) that maintains that cognitive-linguistic noticing of L2 input is requirement to the additional process of that input. Input noticing permits input intake resulting in the creation of form-meaning associations and therefore the final integration of those associations in to the learner developing structure, and general acquisition process. Noticing is important for changing input to intake and refers to paying attention to the occurrence of an event and thus its storage in the memory (Schmidt, 1995). In order to acquire language, learners should attend to and notice language features that are relevant to the target system. Schmidt (1994) distinguishes between 2 levels of awareness: awareness at the level of noticing and awareness at the level of understanding. Noticing, for Schmidt, entails conscious registration of an event; understanding implies recognition of a general principle, rule, or pattern. The awareness at the level of noticing, according to Schmidt, is crucial for learning. Conscious noticing to the linguistic input facilitates the restructuring of the learner's linguistic communication system (Schmidt, 1994). Doughty \& Williams (1998) proposes that input enhancement has 2 forms: a) typographic (written input) enhancement and b) intonational (oral input) enhancement.

The concept of Input Enhancement was put forward by Smith, which refers to the area of language, that some features become salient to facilitate the process of language learning (Smith 1991, 1993). According to Smith (1993) this concept replaced the concept of consciousness-raising (CR). Input enhancement and CR are different because input enhancement does require those changes in the mind in the external environment that may have been deliberately devised by language teachers or textbook writers. The process of second and foreign language learning (EFL/ESL) includes a kind of selection and encoding the available information from the learning setting. According to Schmidt (1990), two factors can facilitate learning process: input attention and input noticing. Later, 
Smith $(1991,1993)$ replaced the consciousness-raising term with input enhancement that the teacher could control.

\subsection{Background of the Study}

The first noticeable study conducting on the efficacy of IE was Shooks'(1994). In his study, two target features of Spanish language were chosen. One was the relative pronouns (quien, que) and the other was the present perfect. Spanish learners participated in this study. They were divided into three groups. First group received enhanced passages (using a larger character size and bolding target forms), and were told to pay attention to the enhanced forms. The same enhanced versions of reading texts received by second group, but they were not told to pay attention to the enhanced target features. Third group was the control group, which received the same materials without typographical modifications, and they were also not told to pay attention to anything in particular. The results showed that performance of subjects in the first two groups, who received the enhanced passages, was significantly better than that of the third group (the control group).

The effective of input enhancement (visual enhancement) in getting language learners to pay attention to the target form was investigated by White (1998). In this study, typographically, the target form was enhanced through underlining, italicization, bolding, and text enlargement. 86 participants, Francophone learners of English, were divided into three groups: first group received input enhancement and extensive reading and listening tasks; the second group received only input enhancement; the third group received no input enhancement. He concluded that all groups "improved in their ability to use" third-person singular possessive in "an oral communication task". In addition, performance of posttests scores for the two groups (who received enhanced forms) was better than that of unenhanced group. The results also revealed that for the delayed posttests (after five weeks), the enhanced group continued to use the target forms in situations that called for their use, compared with other groups. This finding suggested that subjects in the enhanced group benefited from their treatments; although the differences were not significant.

Some researchers (e.g., Izumi, 2002; Jourdenais et al., 1995; Lee, 2007; Leow et al., 2003) showed a way to draw learners' attention to forms by using input enhancement. According to their results, there was a doubt on the efficacy of input enhancement since most of the studies reported that input enhancement did not induce desired learning effects intended by the researchers. As a result, researchers concluded that providing learners with input enhancement alone was too absolute to both draw their attention to form and affect their learning. Some studies (Shahriyarpour \& Abadikhah, 2012; Moaiyedi, 2013) revealed the effective role of input enhancement on the acquisition of target forms. Some studies such as Tabrizi \& Khoii (2011) used input enhancement along with output as the main construction tasks involving learners in the production of input passage.

There has been substantial surge in psycholinguistics since last decade, primarily based on studies that draw learner's attention to specific grammatical items within the input. The theoretical foundation underlying these studies is that the crucial role of attention that plays in promoting process of grammatical acquisition for learners' second/ foreign language (L2) development (e.g., Robinson, 1995; Schmidt, 1994; Tomlin \& Villa, 1994). According to Schmidt's noticing hypothesis conscious attention is very necessary for learning to happen and provides the theoretical foundation for such studies. In line with previous studies, the present study is theoretically based on Schmidt's Noticing hypothesis. In fact, the present research aimed to answer some main questions such as, whether utilizing IE was effective in Iranian EFL context, whether IE instruction could enhance the lexical knowledge of the language learners, and finally whether there was a significant difference between the effectiveness of various types of IE.

\subsection{Resaerch Questions and Hypothses}

This study was an attempt to answer the following questions and hypotheses:

Q1. Does visually input enhancement-based instruction affect Iranian EFL learner's vocabulary acquisition?

Q2. Does auditory input enhancement-based instruction affect Iranian EFL learner's vocabulary acquisition?

Q3. Regarding input enhancement-based instruction, what kind of input enhancement (visual or auditory) is more effective in acquiring the vocabulary in Iranian EFL academic setting?

In addition, there were two null hypotheses posed in the current study:

H01. Visually input enhancement type does not affect Iranian EFL learner's vocabulary acquisition.

H02. Auditory input enhancement does not significantly affect Iranian EFL learner's vocabulary acquisition. 


\section{Method}

\subsection{Participant Characteristics}

Administering an OXFORD PLACEMENT TEST (OPT), the researcher selected those whose scores fell between $( \pm 1)$ standard deviation. Therefore, 75 out of 112 senior Iranian university students majoring English Language Teaching at the university of Applied Science and Technology of Kurdistan University. Their age ranged between 22-26 years old. Gender of participants was not considered as a variable in the study. The participants included three language classes, i.e., a control group and two experimental groups. One experimental group was taught via auditory input enhancement and the other experimental group received visually input enhancement. In addition, the control group received no specific instruction and only followed conventional treatment. Each group consisted of equal number of participants $(\mathrm{N}=25)$.

\subsection{Research Design}

The method in this study was quantitative research and the true experimental design was used in this study, in the way that there were both the experimental and the control groups. That is to say, three groups of participants were randomly selected to undertake the study, two groups as the experimental and another as the control group.

\subsection{Instrumentations}

Three main instruments were utilized in the current research including Oxford Placement Test (OPT), two standard vocabulary pretest, and posttest.

\subsection{Procedure}

First, the Oxford Placement Test was administered among 112 students in four English intact classes at the University of Applied Science and Technology of Kurdistan. Then, based on the placement test, 75 students whose scores fell between $( \pm 1)$ standard deviation were randomly divided into three groups. A pretest was taken for three groups. This pretest consisted of 50 vocabularies, which the participants were expected to finish during the allotted time. One experimental group through visual input enhancement and another experimental group through auditory input enhancement were taught. Through auditory input enhancement the participants were provided with CDs, voice instrument effect, and repeating by the instructor. For instance, at the beginning of the session, the instructor reviewed the target vocabularies. Then, he used the available voice instruments in the language lab and though which he repeated the target words twice and the students were asked to write them and recite it for the next session. In addition, to ensure the learners' complete understanding of the target words, the instructor repeated the words himself three times and checked their pronunciation and related meanings.

In addition, visual input enhancement instruction was designed through utilizing PowerPoint, bolding the target words, highlighting, and underlining them. Here, the instructor provided the subjects with a written text in which the targeted words had been underlined, bolded, and increased the font size. The text was integrated with PowerPoint so that the subjects could see the target words both on PowePoint screen and on the paper. Then, the instructor explained the targeted words and whenever required, the instructor explained the highlighted words on the PowerPoint screen. The instruction period for the experimental groups was 8 sessions and each session lasted half an hour. At the beginning of every session, the instructors in both experimental groups made an attempt to teach target vocabularies in meaningful texts along with their specific instruction. That is, the instructors focused on the target vocabularies and asked the students to pay attention via input enhancement facilities. Finally, after conducting 8 sessions instruction, a posttest with the same content as the pretest was given to all the participants in order to measure their vocabulary achievement in English. Again, the instructors ensured that the enhanced input which they provided for the students was sufficient to gain acceptable level of vocabulary learning. The posttest included 50 multiple-choice questions and was given to the students within the allotted time.

\section{Results}

In order to answer the first and second questions and related hypotheses, the analysis of the pretest of three groups revealed that there were no significant differences between their scores, thus, it was assumed that the groups were similar in terms of their prior English vocabulary proficiency. However, after administering the main instructions, to answer the research questions, one-way ANOVA was conducted. The results of one-way ANOVA revealed a significant difference in how the two experimental groups outperformed on the test compared to their counterpart in the control group, $F(2,49)=52.11, p=004<.05)$. Table 1 , illustrates the results. 
Table 1. The ANOVA results

\begin{tabular}{llllll}
\hline Source of Variance & SS & df & MS & F & Sig. \\
\hline Between groups & 511.43 & 2 & 260.72 & & \\
Within groups & 202.66 & 49 & 4.83 & 52.11 & .0049 \\
Total & 714.09 & 75 & & & \\
\hline
\end{tabular}

In addition, in order to ensure the difference between two experimental groups, and answer the third question independent sample t-test was conducted. Table 2 revealed the results.

Table 2. Independent sample t-test

\begin{tabular}{|c|c|c|c|c|c|c|c|c|}
\hline \multirow[t]{2}{*}{ Groups } & \multirow[t]{2}{*}{$\mathrm{N}$} & \multirow[t]{2}{*}{ Mean } & \multirow[t]{2}{*}{ SD } & \multicolumn{2}{|c|}{$\begin{array}{l}\text { Levene's Test for } \\
\text { Equality of Variances }\end{array}$} & \multicolumn{3}{|c|}{ t-test for Equality of Means } \\
\hline & & & & $\mathrm{F}$ & Sig. & $\mathrm{T}$. & df. & Sig. (2-tailed) \\
\hline EGA & 25 & 9.013 & 1.23 & 1.871 & 0.582 & 3.550 & 49 & 0.318 \\
\hline EGV & 25 & 9.072 & 1.77 & & & & & \\
\hline
\end{tabular}

As it can be seen in Table 2 mean of visually experimental group (EGA) is 9.013, and auditory experimental group (AEG) is 9.072. As mean score of EGA is higher than EGV, Levene Statistic test was run to see whether the difference in mean score in these two groups is significant or not. Based on the significant level of Levene test $0.582>0.05$, homogeneity of variances is confirmed. As the level of significance is $0.318>0.05$ it can be concluded that there is no significant difference between the EGA and EGV groups in pretest. Thus, it can be claimed that any change in the posttest is unlikely to be the effect of preexisting differences between the experimental groups and, instead, it can be attributed to the various treatments that the these groups experienced via input enhancement instruction.

\section{Discussion}

The main purpose of this study was to explore the effect of input enhancement on EFL Iranian EFL students' vocabulary learning. Initially, it was hypothesized that there is no difference between the learners benefiting from input enhancement and those who received no specialized treatment. The results showed significantly greater effect of input enhancement on EFL students' vocabulary learning. These results seem to support the findings of several studies in both second and foreign language learning (Ellis, 1991; Fotos, 1993).

Lee \& Haung (2008) propose that frequency and range of noticing new target forms within input enhancement and therefore vocabulary learning increases as students become more proficient. Although the methods to measure the levels of proficiency and the impact of input enhancement on vocabulary learning are different, the result that input enhancement has a positive effect on EFL learners 'vocabulary learning is the same. Thus, the results of the present study are in line with the previous research findings demonstrating that EFL academic students show greater awareness and higher tendency to benefit from increasing amount of input for vocabulary learning. One possible explanation for such difference would be in terms of students' increasing awareness and knowledge via input enhancement instruction.

Input enhancement can be, therefore, seen as central to effective learning. The most convincing explanation for the same findings of the IE studies might originate the works of Smith from 1991 t0 1994 who put forward the concept of input enhancement. Smith (1994) maintains that the most vivid way to try to influence the subconscious processes is by making the input salient. Thus, it might be argued that findings of the present research lend support to Smith's assumptions (1994) that input enhancement has a positive effect on the rate and accuracy of language acquisition. In addition, the results provide further empirical support for Doughty (1988), Shook (1994), and Williams (1999). However, the utilization of explicit instruction in EFL/ESL teaching profession has been recommended by researchers who believed in the insufficiency of implicit instruction as a means of inducing changes in the learners' interlanguage system (White, 1998). According to Keating (2008), input-enhancement can assist language learning by creating situations where the learners pay special attention to targeted forms. Thus, we would conclude that the results of the present study may highlight the significance of input-enhancement instruction in EFL educational setting. In addition, based on the obtained results, we may infer that during the input enhancement instruction learners have to respond to targeted inputs by signaling their meaning. In the same vein, another possible explanation to support the present results, most Iranian language learners have had the experience of using a type of IE in their instructional learning process, however, 
significance of the IE is either ignored or excluded in educational curriculums. Last but not the least, the results of the present study confirmed the assumption that input enhancement makes the language learners familiarize with the instruction that may promote learning more effectively. IE provides opportunities for more elaborate processing of the target words in the process of language learning.

Finally, the current study has its own limitations: The findings cannot be generalized to all of the EFL Iranian students who are studying English language in settings other than academic settings. Moreover, in the present research only intermediate EFL male and female university students have been investigated. Thus, in order to broaden such kind of studies, the dire need to explore other levels of EFL academic proficiency is evident. However, these limitations are tried to take into consideration (in making conclusion) to prevent detracting the validity of research.

\section{Acknowledgments}

The authors appericate all of the participants from Azad University of Kurdestan, Iran.

\section{References}

Aghajani, B., \& Rahimi, R. (2013). The effect of input enhancement and metalinguistic awareness on learning conditionals by Iranian EFL Learners. Global Journal of Foreign Language Teaching, 3(2), 97-112.

Benati, A., \& Lee, J. (2007). Grammar Acquisition and Processing Instruction: Secondary and Cumulative Effects. Clevedon: Multilingual Matters. http://dx.doi.org/10.1037/10401-000.

Bowles, M. A., \& Leow, R. P. (2005). Reactivity and type of verbal report in SLA research methodology. Studies in Second Language Acquisition, 27, 415-440. http://dx.doi.org/10.1073/pnas.0805417105.

Ellis, R. (1993). Understanding second language acquisition. Oxford: Oxford University Press.

Ellis, R. (2008). Task-based language learning and teaching. Oxford: Oxford University Press.

Larsen-Freeman, D., \& Long, M. (1991). An Introduction to Second Language Acquisition Research. London and New York: Longman.

Lee, J., \&. Hang, A. (2008). Second Language Processing: An Analysis of Theory, Problems and Possible Solutions. London: Continuum.

Leow, R. (2007). The effects of amount and type of exposure on adult learners' L2 development in SLA. Modern Language Journal, 82, 49-68. http://dx.doi.org/10.1073/pnas.0805417105.

Leow, R., \& Morgan-Short, K. (2004). To think aloud or not to think aloud: The issue of reactivity in SLA research methodology. Studies in Second Language Acquisition, 26(1), 35-57.

Lightbown, P. (1985). Great expectations: second language acquisition research and classroom teaching. Applied Linguistics, 6, 173-89. http://dx.doi.org/10.1037/0033-2909.126.6.910.

Lightbown, P., \& Spada, N. (1993). How languages are learned. Oxford: Oxford University Press.

Long, M. H. (1983). Does second language instruction make a difference? A review of research. TESOL Quarterly, 17(3), 359-82.

MacWhinney, B., \& Pléh, C. (1988). The processing of restricted relative clauses in Hungarian. Cognition, 29 , 95-141.

McLaughlin, B., \& Harrington, M. (1989). Second-language acquisition. Annual Review of Applied Linguistics, $10,122-134$.

Norris, J., \& Ortega, L. (2000). Effectiveness of L2 instruction. Language Learning, 50(3), 417-528. http://dx.doi.org/11.1022/0033-2909.125.6.911.

Overstreet, M. (1998). Text enhancement and content familiarity: The focus of learner attention. Spanish Applied Linguistics, 2, 229-258.

Robinson, P. (1995). Attention, memory, and the noticing hypothesis. Language Learning, 45(2), 283-331. http://dx.doi.org/10.1037/1061-4087.45.2.10.

Robinson, P. (2003). Attention and memory during SLA. In C. Doughty \& M. Long (Eds.), Handbook of second language acquisition (pp. 631-678). Oxford: Blackwell.

Sachs, R., \& Polio, C. (2007). Learners' uses of two types of written feedback on a L2 writing revision task. Studies in Second Language Acquisition, 29, 67-100. 
Sanz, C., Lin, H. J., Lado, B., Bowden, H. W., \& Stafford, C. A. (2009). Concurrent verbalizations, pedagogical conditions, and reactivity: two CALL studies. Language Learning, 59(1), 33-71. http://dx.doi.org/10.1041/1061-4087.47.2.16.

Schmidt, R. (1991). The role of consciousness in second language learning. Applied Linguistics, 11, 129-158.

Schmidt, R. (1993). Awareness and second language acquisition. Annual Review of Applied Linguistics, 13, 206-226.

Schmidt, R. (2001). Attention. In P. Robinson (Ed.), Cognition and second language instruction (pp. 3-32). Cambridge: Cambridge University Press.

Schmidt, R. (Eds.). (1995). Attention and awareness in foreign language teaching. Honolulu: University of Hawaii Press

Selinker, L. (1972). Interlanguage. IRAL, 10(3), 209-231. http://dx.doi.org/10.1022/1068-4022.43.2.10.

Shanks, D. R., \& St. John, M. F. (1994). Characteristics of dissociable human learning systems. Behavioral and Brain Sciences, 17, 367-447.

Shook, D. (1994). FL/L2 reading, grammatical information, and the input to intake phenomenon. Applied Language Learning, 5(2), 57-93.

Simard, D. (2009). Alertness, orientation and detection. Studies in Second Language Acquisition, 23, 103-124.

Slobin, D. I. (1987). Thinking for speaking. Proceedings of the Thirteenth Annual Meeting of the Berkeley Linguistics Society (pp. 435-444).

Smith, M. (1993). Input enhancement in instructed SLA. Theoretical Bases. Studies in Second Language Acquisition, 15, 165-179.

Swain, M. (2005). The Output Hypothesis: Theory and Research. In E. Hinkel (Ed.), The Handbook of Research in Second Language Teaching and Learning (pp. 471-483). Hillsdale, NJ: Lawrence Erlbaum Associates.

Swain, M., \& Lapkin, S. (1995). Problems in output and the cognitive processes they generate: A step towards second language learning. Applied Linguistics, 16, 371-391. http://dx.doi.org/10.1037/10762-000.

Tomasello, M. (1998). The new psychology of language: Cognitive and functional approaches to language structure. Mahwah, NJ: Erlbaum.

Tomlin, R., \& Villa, V. (1994). Attention in cognitive science and second language acquisition. Studies in Second Language Acquisition, 16, 183-204. http://dx.doi.org/10.1044/1063-4482.45.2.11.

VanPatten, B. (2003). From Input to Output: A teacher's guide to second language acquisition. New York, USA: McGraw-Hill.

White, J. (1998). Getting the learners attention: A typographical input enhancement study. In C. Doughty \& J. Williams (Eds.), Focus on form in second language classroom acquisition (pp. 85-113). Cambridge: Cambridge University Press.

White, L. (2003). Second Language Acquisition and Universal Grammar. Cambridge: Cambridge University Press.

Williams, J. (1999). Memory, attention, and inductive learning. Studies in Second Language Acquisition, 21, $1-48$.

Wong, W. (2003). The effects of textual enhancement and simplified input on L2 comprehension and acquisition of non-meaningful grammatical form. Applied Language Learning, 14, 109-132.

Wong, W. (2004). The Nature of Processing Instruction. In B. VanPatten (Ed.), Processing Instruction: Theory, research, and commentary (pp. 3-63). Mahwah, NJ: Lawrence Erlbaum.

Wong, W. (2005). Input Enhancement: From Theory and Research to Classroom. New York: McGraw-Hill.

\section{Copyrights}

Copyright for this article is retained by the author(s), with first publication rights granted to the journal.

This is an open-access article distributed under the terms and conditions of the Creative Commons Attribution license (http://creativecommons.org/licenses/by/4.0/). 